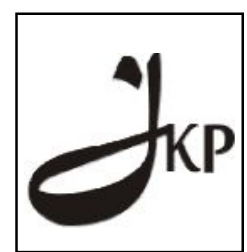

Info Artikel:

Diterima 05/06/2014

Direvisi 12/06/2014

Dipublikasikan 30/06/2014
Jurnal Konseling dan Pendidikan

ISSN Cetak: 2337-6740 - ISSN Online: 2337-6880

http://jurnal.konselingindonesia.com

Volume 2 Nomor 2, Juni 2014, HIm 9-13

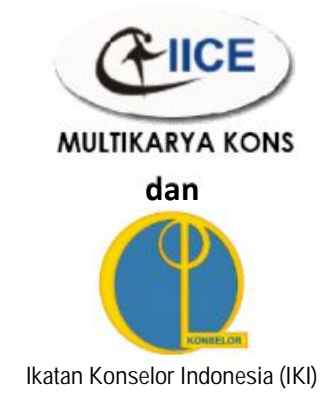

\title{
Perilaku Bolos Siswa dan Implikasinya Terhadap Layanan Bimbingan dan Konseling (Studi Deskriptif Terhadap Siswa SMP N 1 Pasaman)
}

Elsi Novarita

Universitas Negeri Padang

Abstract

Sekolah merupakan salah satu lembaga pendidikan formal yang menyelenggarakan pendidikan untuk pengembangan kemampuan dan potensi siswa. Sebagai lembaga pendidikan, sekolah juga mengajarkan nilai-nilai dan menerapkan aturan yang harus dipatuhi oleh siswa, namun kenyataannnya ada siswa yang melanggar peraturan sekolah salah satunya yaitu membolos. Bolos merupakan ketidak hadiran peserta didik di sekolah tanpa izin. Penelitian ini bertujuan untuk mendeskripsikan tentang perilaku bolos siswa di sekolah. Penelitian ini berbentuk deskriptif. Subjek penelitian ini 27 siswa yang bolos sekolah. Alat pengumpulan data berbentuk angket dan data dianalisis menggunakan teknik persentase melalui bantuan program Microsoft Office Excel. Hasil penelitian mengungkapkan bahwa bentuk perilaku bolos siswa adalah siswa sangat banyak meninggalkan sekolah tanpa izin dan meninggalkan sekolah dengan alasan yang dibuat-buat, faktor yang menyebabkan siswa bolos sekolah sangat banyak bersumber dari individu sendiri dan faktor yang lain banyak bersumber dari keluarga dan sekolah, implikasi layanan bimbingan dan konseling dilihat dari layanan informasi dan layanan konseling perorangan kurang banyak terlibat dalam pengentasan siswa yang membolos.

Keyword: Bolos

Copyright @ 2014 IICE - Multikarya Kons (Padang - Indonesia) dan IKI - Ikatan Konselor Indonesia - All Rights Reserved Indonesian Institute for Counseling and Education (IICE) Multikarya Kons

\section{PENDAHULUAN}

Pada dasarnya pendidikan bertujuan untuk membantu mencapai perkembangan yang optimal sesuai dengan potensi yang dimilikinya, dan melalui pendidikan dapat diwujudkan generasi muda yang berkualitas, baik dalam bidang akademis, religius maupun sosial. Dalam

undang-undang No 20 tahun 2003 tentang Sisdiknas pasal 3 yaitu: "Untuk berkembangnya potensi peserta didik agar menjadi manusia yang beriman dan bertakwa kepada Tuhan yang Maha Esa, berahklak mulia, sehat, berilmu, kreatif, mandiri dan menjadi warga negara yang demokratis serta bertanggung jawab".

Dari kutipan di atas terkandung makna bahwa pendidikan itu menjadikan manusia seutuhnya yaitu Harkat Martabat Manusia (HMM) yang terwujud secara penuh melalui pengembangan kelima dimensi kemanusian dengan mengaktifkan pancadaya secara optimal (Prayitno,1997). 
Dalam hal ini, lembaga yang berperan adalah sekolah. Sekolah sebagai salah satu lembaga pendidikan formal harus menyelenggarakan pendididikan yang berkualitas untuk pengembangan kemampuan dan potensi siswa salah satu wujudnya dari hasil belajar siswa. Selanjutnya, sebagai lembaga pendidikan sekolah juga mengajarkan nilai-nilai dan norma-norma yang berlaku dalam sekolah di samping mengajarkan berbagai keterampilan dan kepandaian kepada siswanya.

Selanjutnya sekolah adalah lingkungan pendidikan sekunder (Sarlito Wirawan, 2012:150). Bagi anak yang sudah bersekolah, lingkungan yang setiap hari dimasukinya selain lingkungan rumah adalah sekolahnya. Sejalan dengan itu sekolah juga merupakan organisasi sosial yang menyediakan layanan pembelajaran bagi siswa. Sebagai organisasi sosial, sekolah merupakan sistem terbuka karena mempunyai hubungan (relasi) dengan lingkungan.

Menurut Semiawan (2012) "lingkungan adalah segala sesuatu di luar individu (eksternal) dan merupakan sumber informasi yang diperolehnya melalui panca indranya". Salah satu lingkungan yang terbukti sangat berperan dalam pembentukan kepribadian murid adalah sekolah.

Dalam hal ini siswa sekolah menengah pertama (SMP) yang memasuki periode tugas perkembangan remaja memerlukan bimbingan dan bantuan untuk mencapai kontribusi yang positif untuk perkembangan jiwanya. Menurut Elida Praytitno (2006:6) masa remaja merupakan salah satu periode dalam rentangan kehidupan manusia. Periode remaja adalah periode dimana individu meninggalkan masa kanak-kanaknya dan mulai memasuki dewasa. Oleh karena itu periode remaja dapat dikatakan periode transisi dari masa kanak-kanak ke masa dewasa.

Pada masa transisi terdapat beberapa kemungkinan yang dapat menimbulkan masa krisis, yang ditandai dengan kecendrungan munculnya perilaku menyimpang. Pada kondisi tertentu perilaku menyimpang akan menjadi perilaku yang mengganggu (Ekowarni,1993). Apabila hal ini dibiarkan dan didukung oleh lingkungan yang kurang kondusif dan sifat kepribadian yang kurang baik akan menjadi pemicu timbulnya berbagai penyimpangan perilaku dan perbuatan negatif yang melanggar aturan dan norma yang ada di masyarakat maupun di sekolah yang biasanya disebut dengan kenakalan remaja. Istilah kenakalan remaja merujuk pada berbagai perilaku, mulai dari perilaku yang tidak dapat diterima secara sosial (seperti berbuat onar di sekolah), status pelanggaran (melarikan diri dari rumah), hingga tindakan kriminal (pencurian).

Dalam proses belajar mengajar muncul perilaku siswa yang mengganggu di lingkungan sekolah yang berpengaruh terhadap diri sendiri dan ada juga yang berpengaruh terhadap orang lain. Berdasarkan hasil wawancara peneliti dengan satu orang guru BK pada hari Sabtu tanggal 10 Maret 2012 di SMP N 1 Pasaman ada siswa kelas VII, VIII dan IX yang pernah merokok dan membolos. Kemudian hasil wawancara peneliti pada hari Senin tanggal 12 Maret 2012 dengan 5 orang siswa yang pernah merampas dalam artian memaksa meminta uang adik kelasnya. Dari keterangan siswa tersebut mereka hanya merampas uang adik kelas sebanyak Rp 5000,-.

Selanjutnya hasil observasi peneliti pada hari Senin tanggal 30 April 2012 adanya siswa yang melanggar peraturan sekolah yaitu siswa laki-laki memakai celana sekolah yang berwarna dongker model pensil dan adanya siswa yang membolos atau cabut dari sekolah. Hal ini (siswa yang membolos) dilakukan siswa pada jam pertama dengan guru bidang studi biologi dan masuk kembali pada jam kedua, dengan siswa tersebut masuk pada jam kedua maka mengganggu proses belajar mengajar siswa di dalam kelas dan mengganggu konsentrasi siswa yang sedang belajar dan guru yang sedang mengajar.

Berdasarkan hasil observasi peneliti pada hari Rabu tanggal 2 Mei 2012 adanya siswa kelas VIII yang berkelahi yaitu sama-sama siswa perempuan. Perilaku siswa yang mengganggu proses belajar mengajar diatas disebut dengan kenakalan remaja. Kenakalan yang dilakukan siswa di atas perlu menjadi persoalan yang dikaji oleh personil sekolah sebab jika tidak dikaji maka remaja akan melakukan kejahatan seperti tindakaan kriminal yaitu perampokan dan tindakan yang biasanya tidak dianggap kriminal yaitu membolos.

Dalam hal ini, siswa yang membolos juga menjadi persoalan yang perlu dikaji oleh personil sekolah, sebab banyak dampak yang bisa merugikan diri siswa. Siswa yang membolos akan mudah nantinya terjerumus ke hal yang melanggar norma hukum seperti narkoba dan obat-obatan terlarang lainnya. 


\section{METODOLOGI}

Penelitian ini berbentuk penelitian deskriptif. Subjek penelitian ini 27 siswa yang membolos. Prosedur yang ditempuh dalam pengumpulan data adalah dengan mengadministrasikan angket kepada subjek penelitian. Data yang telah terkumpul akan dianalisis dengan menggunakan teknik persentase.

\section{HASIL}

Berdasarkan temuan penelitian tentang perilaku bolos siswa dan implikasinya terhadap layanan BK dapat digambarkan sebagai berikut :

Tabel 1

Rekapitulasi Hasil Keseluruhan

Perilaku Bolos Siswa Dan Implikasinya Terhadap Layanan Bimbngan Dan Konseling

\begin{tabular}{|c|c|c|c|}
\hline No & $\begin{array}{l}\text { Aspek yang } \\
\text { diteliti }\end{array}$ & $\%$ & K \\
\hline 1 & $\begin{array}{l}\text { Siswa } \\
\text { meninggalkan } \\
\text { sekolah tanpa izin }\end{array}$ & 87,7 & SB \\
\hline 2 & $\begin{array}{l}\text { Siswa } \\
\text { meninggalkan } \\
\text { sekolah dengan } \\
\text { alasan yang } \\
\text { dibuat-buat }\end{array}$ & 88,8 & SB \\
\hline 3 & $\begin{array}{l}\text { Faktor yang } \\
\text { bersumber dari } \\
\text { individu sendiri }\end{array}$ & 78,4 & SB \\
\hline 4 & $\begin{array}{lr}\text { Faktor } & \text { yang } \\
\text { bersumber } & \text { dari } \\
\text { keluarga } & \end{array}$ & 67,8 & B \\
\hline 5 & $\begin{array}{lr}\begin{array}{l}\text { Faktor } \\
\text { bersumber }\end{array} & \text { yang } \\
\text { sekolah } & \text { dari } \\
\end{array}$ & 73,0 & B \\
\hline 6 & Layanan informasi & 31,1 & $\mathrm{~KB}$ \\
\hline 7 & $\begin{array}{l}\text { Layanan konseling } \\
\text { perorangan }\end{array}$ & 29,0 & $\mathrm{~KB}$ \\
\hline
\end{tabular}

Berdasarkan tabel 1 di atas dikemukakan pembahasan tentang bentuk bolos yang dilakukan siswa yang dibagi menjadi dua indikator yaitu siswa meninggalkan sekolah tanpa izin dan siswa meninggalkan sekolah dengan alasan yang dibuat-buat, hasil analisis data dilapangan menyatakan bahwa siswa dikategorikan sangat banyak meninggalkan sekolah tanpa izin dan meninggalkan sekolah dengan alasan yang dibuat-buat.

Menurut Elizabeth Hurlock (1978:140) jenis bolos yang dilakukan siswa berupa siswa meninggalkan sekolah tanpa izin dan siswa meninggalkan sekolah dengan alasan yang dibuat-buat. Siswa pergi sesuka hati mereka tanpa diketahui oleh guru atau kepala sekolah dan mereka juga meninggalkan sekolah pada jam pelajaran sambil mengeluh meresa tidak enak badan atau orang tua menyuruh cepat pulang.

Selanjutnya faktor penyebab siswa bolos sekolah dilihat dari tiga indikator yaitu siswa sangat banyak bolos sekolah bersumber dari individu sendiri, sedangkan faktor lainnya siswa banyak bolos sekolah bersumber dari faktor keluarga dan sekolah. 
Menurut Ali Imron (2011:84) faktor penyebab siswa bolos sekolah ada tiga yaitu:

1. Faktor yang bersumber dari individu sendiri yaitu terjadinya perkelahian antar siswa dan prestasinya lemah.

2. Faktor yang bersumber dari keluarga yaitu kedua orang tua bekerja sehingga pengawasan orang tua terhadap siswa kurang dalam hal pendidikan, adanya masalah dilingkungan keluarga dan letak rumah yang jauh dari sekolah.

3. Faktor yang bersumber dari sekolah yaitu lokasi sekolah tidak menyenangkan, fasilitas sekolah yang kurang memadai, suasana sekolah kurang kondusif dan bimbingan guru kepada siswa kurang, baik secara kelompok maupun secara individual.

\section{IMPLIKASI TERHADAP LAYANAN BIMBINGAN DAN KONSELING}

Pelayanan bimbingan dan konseling adalah suatu pelayanan yang dapat mengatasi permasalahan yang dialami siswa dan dapat memandirikan sikap siswa menjadi lebih baik. Berdasarkan hasil wawancara dan observasi pada bab pertama terlihat sebagian siswa SMP N 1 Pasaman ada yang melakukan kenakalan remaja salah satunya adalah bolos sekolah dan hal ini juga terlihat pada identifikasi masalah pada bab pertama.

Hasil penelitian menunjukkan bahwa perilaku bolos siswa di sekolah dilihat dari bentuknya, siswa sangat banyak meninggalkan sekolah tanpa izin dan meningalkan sekolah dengan alasan yang dibuat-buat. Hal ini diharapakan, melalui layanan bimbingan dan konseling dapat membantu siswa yang sangat banyak bolos melakukan perilaku bolos menjadi tidak banyak bolos.

Dalam pelaksanaan praktek bimbingan dan konseling, semua jenis layanan dalam bimbingan dan konseling dapat mengarahkan siswa yang membolos menjadi siswa yang rajin dan taat pada peraturan sekolah.

Menurut Dewa Ketut Sukardi (2008:38) bimbingan dan konseling adalah upaya pemberian bantuan yang diberikan kepada konseli supaya dia memperoleh konsep diri dan kepercayaan diri sendiri untuk di manfaatkan olehnya dalam memperbaiki tingkah lakunya dimasa akan datang.

Berdasarkan tabel 1 implikasi layanan bimbingan dan konseling dilihat dari layanan informasi dan layanan konseling perorangan kurang banyak terlibat dalam pengentasan siswa yang bolos sekolah.

Sesuai dengan peran guru BK di sekolah sebagai salah satu pendidik yang bertanggung jawab terhadap perkembangan siswa, maka guru BK harus memberikan layanan bimbingan dan konseling kepada siswa yang bolos sekolah agar menjadi siswa yang taat pada peraturan yang berlaku di sekolah. Namun, layanan yang bisa diberikan oleh guru BK dalam permasalahan ini adalah

a. Layanan informasi

Layanan informasi sangat penting dalam pelayanan bimbingan dan konseling, Layanan ini berfungsi untuk memberikan informasi yang dibutuhkan siswa. Menurut Prayitno dan Erman Amti (1999:259) mengemukakan Layanan informasi yaitu bertujuan dengan memberikan informasi kepada individu yang berkepentingan tentang berbagai hal yang di perlukan untuk menjalani tugas atau kegiatan.

Penerapan layanan informasi yang dilaksanakan oleh guru BK bisa dengan topik akibat perilaku bolos sekolah. Dalam pemberian topik ini, guru BK harus bisa memberikan informasi dengan bahasa yang mudah dipahami siswa dan cara penyampainnya juga menarik perhatian siswa agar siswa cepat memahaminya dan menerapkannya dalam kehidupan sehari-hari.

b. Layanan konseling perorangan

Prayitno (2004:1) mengemukakan layanan konseling perorangan merupakan layanan konseling yang diselenggarakan oleh seorang konselor terhadap seorang klien dalam rangka pengentasan masalah pribadi klien.

Penerapan layanan konseling perorangan yang dilaksanakan guru bimbingan dan konseling (BK) memberikan bantuan kepada siswa yang sedang melaksanakan konseling perorangan secara langsung berupa arahan dan meyakinkan siswa bahwa perilaku bolos yang dilakukan siswa itu salah dan dampak perilaku bolos bisa mempengaruhi hasil belajar. 


\section{PENUTUP}

Berdasarkan temuan penelitian yang telah dilakukan tentang perilaku bolos siswa, maka dapat diambil kesimpulan sebagai berikut:

1. Bentuk perilaku bolos siswa adalah siswa sangat banyak meninggalkan sekolah tanpa izin dan meninggalkan sekolah dengan alasan yang dibuat-buat

2. Faktor yang menyebabkan siswa bolos sekolah sangat banyak bersumber dari individu sendiri dan faktor yang lain banyak bersumber dari keluarga dan sekolah.

3. Implikasi layanan bimbingan dan konseling dilihat dari layanan informasi dan layanan konseling perorangan kurang banyak terlibat dalam pengentasan siswa bolos sekolah

\section{DAFTAR PUSTAKA}

Ali, Imron. 2011. Manajemen Peserta Didik Berbasis Sekolah. Jakarta: Bumi Aksara

Dewa, Ketut.S. 2008. Pengantar Pelaksanaan Program Bimbingan dan Konseling. Jakarta. Rineka Cipta

Ekowarni. 1993. Prilaku Menyimpang.http:// damandiri.co.id di akses tanggal 3 oktober 2012

Elida, Prayitno. 2006. Psikologi Perkembangan Remaja.Padang:Angkasa Raya

Elizabeth, Hurlock. 1978.Perkembangan anak. Jakarta:Erlangga

Prayitno. 1997. Seri Pemandu Pelaksanaan Layanan Bimbingan dan Konseling di Sekolah Menengah Pertama.Padang:Universitas Negri Padang

Prayitno dan Erman Amti. 1999. Dasar-Dasar Bimbingan dan Konseling.Jakarta:PT.Rineka Cipta

Prayitno.2004. Seri Layanan Konseling L1-L9.Padang:Universitas Negri Padang

Sarlito Wirawan. 2012. Psikologi Remaja.Jakarta:PT.Raja Grafindo Persada

Semiawan.2012.Pengertian Lingkungan.http://blogspot.com di akses tanggal 3 Otober 2012 